\title{
Histopathological Grade versus Estrogen and Progestron Receptor Status in Carcinoma Breast- A Single Center Study
}

\author{
Amit Mittal*, CSBR Prasad, Sreeramulu PN, Srinivasan D, Naveedahmed khan and Ruta Ujjval Joshi \\ Department of General Surgery and pathology, Sri Devaraj Urs Medical College, India
}

Submission: May 23, 2017; Published: June 02, 2017

*Corresponding author: Amit Mittal, Department of General Surgery and pathology, Sri DevarajUrs Medical College, Kolar-563101, Karnataka, India, Email: dr.asmittal@gmail.com

\begin{abstract}
Objective: The role of hormone receptors as a prognostic and therapeutic tool in breast cancer is widely accepted. The aim of this study was to analyze the receptor status in breast cancer with histopathological characteristics of the tumor.

Methods: In the present study, immunohistochemical assay of 62 tumor block of patients of breast carcinoma was performed to know the hormone receptor status as well as histological examination.

Results: 62 samples were taken to study hormonal status and their relation with histo-pathological factors. Out of 62 breast cancer specimen available for immunohistochemical testing for ER/PR. The result of the study showed $45.16 \%$ cases were $\mathrm{ER}+\mathrm{PR}+, 4.84 \%$ cases ER+/PR-, $6.45 \%$ ER-/PR+ and 43.55\% cases were ER-/PR-. A significant association was seen between histologic grade and hormone receptor status.

Conclusion: The Estrogen receptor and Progestron Receptor negative cases were found to be high grade disease on histological evaluation. The ER/PR status of all breast tumour should be evaluated for IHC. ER/PR positive breast tumour has better prognosis and respond better to treatment.

Keywords: Breast carcinoma; Estrogen; Progesterone; Histopathology

Abbreviations: ER: Estrogen Receptor; PR: Progesterone Receptor; Her2: Human Epidermal Growth Factor Receptor-2; H\&E: Hematoxylin and
\end{abstract} Eosin; HPF: High- Power Fields

\section{Introduction}

Breast cancer is the most common cancer in women worldwide, with nearly 1.7 million new cases diagnosed in 2012 (second most common cancer overall). This represents about $12 \%$ of all new cancer cases and $25 \%$ of all cancers in women [1]. Breast cancer is a leading cause of death in women [2]. Incidence of breast cancer is low in India compared to western countries, but it is associated with poor prognosis and high mortality, may be due to late presentation at advanced stages [3]. It shows heterogeneity in its clinical behavior. Prognosis and management of breast cancer are influenced by the classic variables such as histological type and grade, tumor size, lymph node status, status of hormonal receptors- estrogen receptor (ER) and Progesterone receptor (PR) of tumor [4]. Determining the estrogen receptor (ER), progesterone receptor (PR) and human epidermal growth factor receptor-2 (Her2/neu) receptor status in breast cancer has become practice as survival advantage for patients with hormones receptor positive status by treatment with adjuvant hormonal or chemotherapeutic regimens . It is well known that strong ER-positive cases benefit from endocrine therapy alone, in contrast to those with low to moderate ER positivity [5].

PR status is independently associated with disease-free and overall survival. Patients with ER, PR positive tumors have a better prognosis than patients with negative expression of ER and PR tumors [6]. Immunohistochemistry is primarily a research tool in our population. Hormone receptors study is not routinely measured as it is expensive. This could impact treatment decisions and patients are sometimes treated empirically with tamoxifen which is not always required. The present study was planned keeping in mind predictive importance of receptor status for the prognosis of illness and application of appropriate therapy. The objective was to determine receptor status and it's correlation with histopathological Grade of the tumor in an Indian population. 


\section{Objectives}

To correlate the Histopathological grade with ER and PR receptor status of breast carcinoma

\section{Materials and Methods}

This was an observational study carried out in R L Jalappa Hospital, Tamaka, Kolar. Samples of Sixty two patients with histological proven diagnosis of breast carcinoma from January 2011 to December 2015 were selected for this study. Modified radical mastectomy specimens were subjected for routine histopathological examination and Immunohistochemical analysis. Clinical details were archived from the files. Specimens were routinely fixed 24-48 hours in 10\% neutral buffer formalin and were grossly examined and representative tissue bits were taken according to standard guidelines and then processed. Sections were stained with routine hematoxylin and eosin (H\&E) stain. Histopathological features were determined. amples Swere histologically graded according to Modified Bloom-RichardsonElston grading system. ER / PR status was evaluted by immunohistochemistry technique with monoclonal antibodies (DAKO) using antigen-antibody Streptavidin immunoperoxidase technique and other tumor related parameters were reported as per standards. ER and PR positivity was assessed using Allred Score system. The Allred score combines the percentage of positive cells and the intensity of the reaction product in the most of the carcinoma. The 2 scores are added together for a final score with 8 possible values. A simplified Allred score groups 0 and 2; 3 and 4; 5 and 6; and 7 and 8 for 4 possible values [7] (Tables 1 \& 2).

Table 1: Proportion score (PS).

\begin{tabular}{|c|c|}
\hline Score & \% of Positive cells \\
\hline 0 & 0 \\
\hline 1 & $<1$ \\
\hline 2 & $1-10$ \\
\hline 3 & $11-33$ \\
\hline 4 & $34-66$ \\
\hline 5 & $67-100$ \\
\hline Intensity score & Intensity of positivity \\
\hline 0 & None \\
\hline 1 & Weak \\
\hline 2 & Intermediate \\
\hline 3 & Strong \\
\hline
\end{tabular}

Table 2: The proportion score and intensity score are added together for a total score.

\begin{tabular}{|c|c|}
\hline Total score: PS+ IS & Interpretation \\
\hline 0,2 & Negative \\
\hline $3,4,5,6,7,8$ & Positive \\
\hline
\end{tabular}

Elston- Ellis modification of Scarff- Bloom-Richardson grading system was used for histological grade. It evaluates the amount of tubule formation, the extend of nuclear pleomorphism and the mitotic count. Each variable is given a score of 1, 2, or 3 and the score are added to produce a grade. 2 The mitotic score was determined by the number of mitotic figures found in 10 consecutive high- power fields (HPF) in the most mitotically active part of the tumor. Only clearly identifiable mitotic figures were counted. Diagnosis age was categorized as $<30,30-39,40$ $49,50-59$ and $\geq 60$ yrs.

\section{Results}

Sixty two cases of breast carcinomas cases were tested for ER and PR status in relation to histological grading of tumor. In the present study female patients with breast carcinoma were aged between $3^{\text {rd }}$ and $8^{\text {th }}$ decade of life. The youngest was 25 years and oldest 79 years the mean age was 52.66 years. Majority (63\%) were in age group of 40 to 59 yrs (Table 3).

Table 3: Age distribution of the patients.

\begin{tabular}{|c|c|}
\hline AGE GROUP (In Yrs ) & NUMBER OF CASES \\
\hline$<30$ & 1 \\
\hline $30-39$ & 8 \\
\hline $40-49$ & 14 \\
\hline $50-59$ & 19 \\
\hline$\geq 60$ & 20 \\
\hline
\end{tabular}

The morphological categories were infiltrating ductal carcinoma, not otherwise specified (52 cases- $83.9 \%$ ) followed by medullary carcinoma (6 cases, $9.7 \%$ ); infiltrating lobular carcinoma (2 cases- $3.2 \%$ ); mucinous carcinoma and infiltrating papillary carcinoma $1(0.7 \%)$ case each (Table 4$)$.

Table 4: Number of patients in different morphological categories.

\begin{tabular}{|c|c|}
\hline Morphological Categories & No of Cases \\
\hline Infiltrating Ductal Carcinoma(NOS) & 52 \\
\hline Medullary Carcinoma & 6 \\
\hline Mucinous Carcinoma & 1 \\
\hline Infiltrating Lobular Carcinoma & 2 \\
\hline Infiltrating Papillary Carcinoma & 1 \\
\hline
\end{tabular}

The most frequent tumor grade was grade I (49\%) followed by grade III ( $40 \%)$ and grade II (11\%) (Table 3 ). The result of the study showed $45.16 \%$ cases were ER+/PR+, $4.84 \%$ cases ER+/ PR-, 6.45\% ER-/PR+ and 43.55\% cases were ER-/PR. Expression of ER and PR found to be significantly associated with tumor grade $(\mathrm{p}=0.02)$ (Tables $5-8)$.

Table 5: Frequency of tumor grade.

\begin{tabular}{|c|c|c|}
\hline Histological grade & No of cases & Percentage \\
\hline Grade I & 30 & $49 \%$ \\
\hline Grade II & 7 & $11 \%$ \\
\hline Grade III & 25 & $40 \%$ \\
\hline
\end{tabular}


Table 6: ER status in relation to histological grade of tumor.

\begin{tabular}{|c|c|c|c|}
\hline $\begin{array}{c}\text { Grade of } \\
\text { tumor }\end{array}$ & $\begin{array}{c}\text { No. of cases } \\
\text { (\%) }\end{array}$ & $\begin{array}{c}\text { ER positive } \\
\text { Frequency (\%) }\end{array}$ & $\begin{array}{c}\text { ER negative } \\
\text { Frequency (\%) }\end{array}$ \\
\hline I & 30 & 26 & 4 \\
\hline II & 7 & 4 & 3 \\
\hline III & 25 & 1 & 24 \\
\hline
\end{tabular}

Table 7: PR status in relation to histological grade of tumor.

\begin{tabular}{|c|c|c|c|}
\hline $\begin{array}{c}\text { Grade of } \\
\text { tumor }\end{array}$ & $\begin{array}{c}\text { No. of cases } \\
\text { (\%) }\end{array}$ & $\begin{array}{c}\text { PR positive } \\
\text { Frequency (\%) }\end{array}$ & $\begin{array}{c}\text { PR negative } \\
\text { Frequency (\%) }\end{array}$ \\
\hline I & 30 & 26 & 4 \\
\hline II & 7 & 4 & 3 \\
\hline III & 25 & 2 & 23 \\
\hline
\end{tabular}

Table 8: ER/PR status in relation to histological grade of tumor.

\begin{tabular}{|c|c|c|c|}
\hline $\begin{array}{c}\text { Grade of } \\
\text { Tumor }\end{array}$ & $\begin{array}{c}\text { No. of cases } \\
\text { (\%) }\end{array}$ & $\begin{array}{c}\text { ER/PR positive } \\
\text { Frequency (\%) }\end{array}$ & $\begin{array}{c}\text { ER/PR } \\
\text { negative } \\
\text { Frequency (\%) }\end{array}$ \\
\hline I & 30 & 26 & 0 \\
\hline II & 7 & 2 & 2 \\
\hline III & 25 & 0 & 24 \\
\hline
\end{tabular}

\section{Discussion}

Improved breast cancer treatment requires integration of clinical pathology and cancer biology which could affect patient outcome. ER, PR and her2/neu are well-established procedures in routine breast cancer management mainly as prognostic factors for adjuvant hormone therapy $[8,9]$. In our study, expression of ER, PR was found to be $48.39 \%, 41.9 \%$ respectively which correlate well with other studies $[10,11]$. Hormonal receptor status has shown that overall positivity rate for ER and PR was lower in India than that reported in Western literature. In European and American population, 60-80\% patients were found with positive receptor expression [10]. This may be due to lower average age at diagnosis or racial difference.

The tumor grade I were more common in our study followed by grade III and II contrast to other studies [12]. This is a similar to some other studies where well-differentiated breast cancer is more common than the poorly differentiated cancer $[10,13]$. In our study, ER and PR correlated well with grade I ( $p=0.001$ and $\mathrm{p}=0.02$ respectively). Tumor size is one of the important predictors of tumor behavior in breast cancer. Our results described the significant association of tumor size with an expression of ER and PR ( $p=0.02 \& p=0.04)$ respectively. Our results confirmed that non-reactivity of hormonal receptors increases with increase in tumor size.

Infiltrating ductal carcinoma was the most common histological type similar to other studies followed by medullary carcinoma in our study where as in other studies Infiltrating lobular carcinoma being the second most common type $[14,15]$.
Our study provides convincing evidence for a non-significant association between expression of ER, PR and lymph node metastasis. Similar results have been documented in other studies $[16,17]$.

\section{Conclusion}

Immunohistochemical analysis of ER and PR receptors is widely available at a reasonable cost and is prognostic as well as somewhat predictive. This study confirms that receptor expression of ER and PR found to be significantly associated with tumor grade and tumor size. However, No association with node metastasis and ER, PR expressions was observed. Further functional analyzes of ER and PR receptors are needed to investigate the effects of compounds in inhibiting cancer in humans. These findings could have clinical importance in breast cancer treatment.

\section{References}

1. Ferlay J, Soerjomataram I, Dikshit R, Eser S, Mathers C, et al. (2015) Cancer incidence and mortality worldwide: sources, methods and major patterns in GLOBOCAN 2012. Int J Cancer 136(5): E359-386.

2. Singhai R, Patil VW, Patil AV (2011) Status of HER-2/neu receptors and Ki-67 in breast cancer of Indian women. Int J App Basic Med Res 1(1): 15-19.

3. Roy I, Othieno E (2011) Breast carcinoma in Uganda: Microscopic study and receptor profile of 45 cases. Arch Pathol Lab Med 135(2): 194-199.

4. Sharif MA, Mamoon N, Mustaq S, Khadim MT (2009) Morphological profile and association of HER-2/Neu with Prognostic markers in Breast carcinoma in Northern Pakistan. J Coll Physicians Surg Pak 19(2): 99-103.

5. Allred DC, Harvey JM, Berardo M, Clark GM (1998) Prognostic and predictive factors in breast cancer by immunohistochemical analysis. Mod Pathol 11(2): 155-168.

6. Bardou VJ, Arpino G, Elledge RM, Osborne CK, Clark GM (2003) Progesterone receptor status significantly improves outcome prediction over estrogen receptor status alone for adjuvant endocrine therapy in two large breast cancer databases. J Clin Oncol 21(10): 1973-1979.

7. Umemura S, Kurosumi M, Moriya T, Oyama T, Arihiro K, et al. (2006) Immunohistochemical evaluation for hormone receptors in breast cancer: a pratically useful evaluation system and handling protocol. Breast Cancer 13(3): 232-235.

8. Donegan WL (1997) Tumor-related prognostic factors for breast cancer. Cancer J Clin 47(1): 28-51.

9. Bast RC, Ravdin P, Hayes DF, Bates S, Fritsche H, et al. (2001) 2000 update of recommendations for use of tumor markers in breast and colorectal cancer: clinical practice guidelines of American Society of Clinical Oncology. J Clin Oncol 19(6): 1865-1878.

10. Mudduwa LK (2009) Quick score of hormone receptor status of breast carcinoma: Correlation with the other clinicopathological prognostic parameters. Indian J Pathol Microbiol 52(2): 159-163.

11. Kaul R, Sharma J, Minhas SS, Mardi K (2011) Hormone receptor status of breast cancer in the himalayan region of northern India. Indian J Surg 73(1): 9-12.

12. Biesterfield S, Schroder W (1979) Simultaneous histochemical and biochemical hormone receptor assessment in breast cancer provides complementary prognostic information. Aus Cancer Res 7: 4723-4729. 
13. Suvarchala SB, Nageswararao R (2011) Carcinoma breasthistopathological and hormone receptors correlation. J Biosci Technol 2(4): 340-348.

14. Hall IJ, Moorman PG, Millikan RC, Newman B (2005) Comparative analysis of breast cancer risk factors among African- Americal women and white women. Am J Epidemol 161(1): 40-51.

15. Jatoi I, Anderson WF, Rao SR, Devesa SS (2005) Breast cancer trends among black and white women in the United States. J clin Oncol 23(31): 7836-7841.

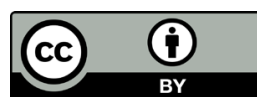

This work is licensed under Creative Commons Attribution 4.0 Licens

DOI: 10.19080/OAJS.2017.04.555639
16. Ariga R, Zarif A, Korasick J, Reddy V, Siziopicou K, et al. (2005) Correlation of Her-2/neu gene amplification with other prognostic and predictive factors in female breast carcinoma. Breast J 11(4): 278-280.

17. Bozcuk H, Uslu G, Pestereli E, Samur M, Ozdogan M, et al. (2001) Predictor of distant metastasis at a presentation in breast cancer: a study also evaluating associations among common biological indicators. Breast Cancer Res Treat 68(3): 239-248.

\section{Your next submission with Juniper Publishers will reach you the below assets}

- Quality Editorial service

- Swift Peer Review

- Reprints availability

- E-prints Service

- Manuscript Podcast for convenient understanding

- Global attainment for your research

- Manuscript accessibility in different formats

( Pdf, E-pub, Full Text, Audio)

- Unceasing customer service

Track the below URL for one-step submission https://juniperpublishers.com/online-submission.php 